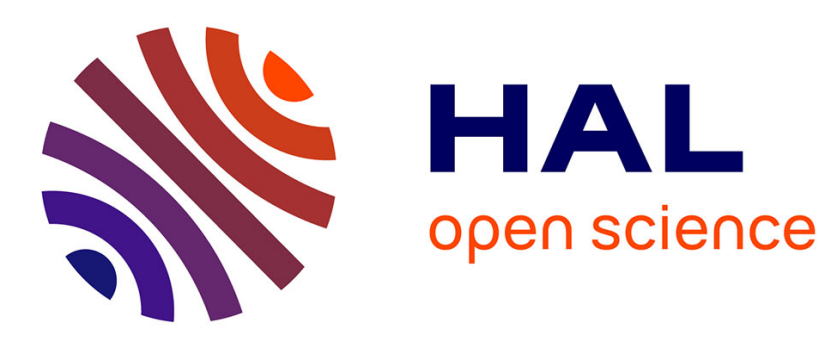

\title{
Determination of Rate Constants for the Activation Step in Atom Transfer Radical Polymerization Using the Stopped-Flow Technique
}

Tomislav Pintauer, Wade Braunecker, Edmond Collange, Rinaldo Poli, Krzysztof Matyjaszewski

\section{To cite this version:}

Tomislav Pintauer, Wade Braunecker, Edmond Collange, Rinaldo Poli, Krzysztof Matyjaszewski. Determination of Rate Constants for the Activation Step in Atom Transfer Radical Polymerization Using the Stopped-Flow Technique. Macromolecules, 2004, 37 (8), pp.2679-2682. 10.1021/ma035634f . hal03280617

\section{HAL Id: hal-03280617 https://hal.science/hal-03280617}

Submitted on 8 Jul 2021

HAL is a multi-disciplinary open access archive for the deposit and dissemination of scientific research documents, whether they are published or not. The documents may come from teaching and research institutions in France or abroad, or from public or private research centers.
L'archive ouverte pluridisciplinaire HAL, est destinée au dépôt et à la diffusion de documents scientifiques de niveau recherche, publiés ou non, émanant des établissements d'enseignement et de recherche français ou étrangers, des laboratoires publics ou privés. 


\title{
Determination of Rate Constants for the Activation Step in
}

\section{Atom Transfer Radical Polymerization Using the Stopped-}

Flow Technique

\author{
Tomislav Pintauer, ${ }^{\mathrm{a}}$ Wade Braunecker, ${ }^{\mathrm{a}}$ Edmond Collange, ${ }^{\mathrm{b}}$ \\ Rinaldo Poli ${ }^{*}$ and Krzysztof Matyjaszewski ${ }^{* a}$
}

${ }^{a}$ Department of Chemistry, Carnegie Mellon University, 4400 Fifth Avenue, Pittsburgh, PA 15213, USA

${ }^{b}$ Laboratoire de Synthèse et d'Electrosynthèse Organométalliques, Faculté des Sciences

"Gabriel", Université de Bourgogne, 6 Boulevard Gabriel, 21000 Dijon, France

${ }^{c}$ Laboratoire de Chimie de Coordination, 205 Route de Narbonne, 31077 Toulouse

Cedex, France

\begin{abstract}
The stopped-flow technique was used to determine the activation rate constants $\left(\mathrm{k}_{\mathrm{act}}\right)$ and activation rate parameters $\left(\Delta \mathrm{H}^{\neq}\right.$and $\left.\Delta \mathrm{S}^{\neq}\right)$in $\mathrm{CH}_{3} \mathrm{CN}$ for a series of alkyl halides (PEBr, MBrP, and $\mathrm{EBriB})$ and $\mathrm{Cu}^{\mathrm{I}} \mathrm{X} / \mathrm{L}_{\mathrm{n}}$ complexes $\left(\mathrm{L}_{\mathrm{n}}=\mathrm{dNbpy}\right.$, PMDETA, and $\left.\mathrm{Me}_{6} \mathrm{TREN}\right)$. The activation rate constants for EBriB were found to increase in the order $\mathrm{Cu}^{\mathrm{I}} \mathrm{Br} / 2 \mathrm{dNbpy}<\mathrm{Cu}^{\mathrm{I}} \mathrm{Br} / \mathrm{PMDETA}<<\mathrm{Cu}^{\mathrm{I}} \mathrm{Br} / \mathrm{Me}_{6} \mathrm{TREN}$. The rate constants of activation for $\operatorname{PEBr}\left(8.6 \times 10^{2} \mathrm{M}^{-1} \mathrm{~s}^{-1}\right), \operatorname{MBrP}\left(1.1 \times 10^{3} \mathrm{M}^{-1} \mathrm{~s}^{-1}\right)$ and $\operatorname{EBriB}\left(7.7 \times 10^{3} \mathrm{M}^{-1} \mathrm{~s}^{-1}\right)$ at $25^{\circ} \mathrm{C}$
\end{abstract}


for $\mathrm{Cu}^{\mathrm{I}} \mathrm{Br} / \mathrm{Me}_{6} \mathrm{TREN}$ complex were found to be orders of magnitude higher than for the corresponding $\mathrm{Cu}^{\mathrm{I}} \mathrm{Br} / 2 \mathrm{dNbpy}$ and $\mathrm{Cu}^{\mathrm{I}} \mathrm{Br} / \mathrm{PMDETA}$ complexes. The demonstrated effectiveness of the stopped-flow technique to measure fast reaction rates opens the door to systematically determine activation rate constants and activation parameters for other highly active ATRP complexes.

Keywords: atom transfer radical polymerization, ATRP, copper complexes, activation rate constant, stopped-flow. 
The synthesis of macromolecules with well-defined compositions, architectures and functionalities represents an ongoing effort in the field of polymer chemistry. Over the past few years, atom transfer radical polymerization (ATRP) has emerged as a very powerful and robust technique to meet these goals. ${ }^{1-3}$ The basic working mechanism of ATRP (Scheme 1) involves a reversible switching between two oxidation states of a transition metal complex. ${ }^{4,5}$ Typically, copper(I) halide is used in conjunction with a nitrogen based complexing ligand. ${ }^{4,6-9}$

\section{[Insert Scheme 1]}

Homolytic cleavage of the alkyl halogen bond $(\mathrm{R}-\mathrm{X})$ by $\mathrm{Cu}^{\mathrm{I}} \mathrm{X} / \mathrm{L}_{\mathrm{n}}$ generates an alkyl radical $\mathrm{R}^{\bullet}$ and the corresponding $\mathrm{Cu}^{\mathrm{II}} \mathrm{X}_{2} / \mathrm{L}_{\mathrm{n}}$ complex. The radical $\mathrm{R}^{\bullet}$ can propagate with a rate constant $\mathrm{k}_{\mathrm{p}}$, by adding to the double bond of a vinyl monomer, terminate by either coupling or disproportionation $\left(\mathrm{k}_{\mathrm{t}}\right)$, or be reversibly deactivated by the $\mathrm{Cu}^{\mathrm{II}} \mathrm{X}_{2} / \mathrm{L}_{\mathrm{n}}$ complex $\left(\mathrm{k}_{\text {deact }}\right)$. Radical termination is diminished as a result of the persistent radical effect, ${ }^{10}$ and the equilibrium is strongly shifted towards the dormant species ( $\mathrm{k}_{\mathrm{act}} \ll \mathrm{k}_{\mathrm{deact}}$ ). Consequently, polymers with predictable molecular weights, narrow molecular weight distributions and high functionalities have been synthesized. ${ }^{11-16}$

Fundamental studies are crucial to future developments in the ATRP. Factors that deserve consideration in such a study include the determination of the rate constants of elementary reactions occurring in the ATRP such as activation, deactivation and initiation. ${ }^{17-25}$ Even more important is the correlation of these rate constants with such reaction parameters as catalyst, alkyl halide and monomer structure, temperature and solvent. ${ }^{26-29}$ These investigations can potentially optimize the development of catalysts 
for particular monomers and reaction conditions and generally improve the overall catalytic process.

In this paper, we report the use of stopped-flow techniques to measure very fast activation rate constants for model systems in copper-mediated ATRP which were previously not investigated due to the limitations in current methods which are mostly based on NMR and GC measurements. Furthermore, the activation parameters for some of the model systems are reported.

Activation rate constants $\left(\mathrm{k}_{\mathrm{act}}\right)$ in the ATRP are typically determined from model studies in which the transition metal complex is reacted with alkyl halide in the presence of radical trapping agents such as TEMPO. ${ }^{18,19,30}$ The rates are typically determined by monitoring the rate of disappearance of the alkyl halide in the presence of excess activator $\left(\mathrm{Cu}^{\mathrm{I} X} / \mathrm{L}_{\mathrm{n}}\right)$ and excess TEMPO which traps radicals faster than $\mathrm{Cu}^{\mathrm{II}} \mathrm{X}_{2} / \mathrm{L}_{\mathrm{n}} \cdot{ }^{18,31-34}$ Under such conditions, the activation rate constant can be kinetically isolated from the deactivation rate constant and is given by $\ln \left([\mathrm{RX}]_{0} /[\mathrm{RX}]_{\mathrm{t}}\right)=-\mathrm{k}_{\mathrm{act}}\left[\mathrm{Cu}^{\mathrm{I} X} / \mathrm{L}_{\mathrm{n}}\right]_{0} \mathrm{t}(\mathrm{Scheme}$ 2). ${ }^{18}$ The values were also determined for some polymeric

\section{[Insert Scheme 2]}

systems using GPC techniques and similar kinetic expressions. ${ }^{20}$ However, both methods are limited in measuring fast rate constants with the maximum upper limit of approximately $2 \mathrm{M}^{-1} \mathrm{~s}^{-1}$. This prompted us to consider the stopped-flow technique for measuring very fast activation rate constants for model systems in copper-mediated ATRP, since the mixing time (ca. $1 \mathrm{~ms}$ ) and speed of data collection (one full spectrum every ca. $1 \mathrm{~ms}$ for diode-array UV-visible spectrophotometers) allow the measurement of 
pseudo-first order rate constants up to ca. $1.5 \cdot 10^{2} \mathrm{~s}^{-1}\left(\mathrm{t}_{1 / 2}=\mathrm{ca} .5 \mathrm{~ms}\right)$. The structures of model alkyl halides and complexing ligands used in conjunction with $\mathrm{Cu}^{\mathrm{I}} \mathrm{Br}$ or $\mathrm{Cu}^{\mathrm{I}} \mathrm{Cl}$ are shown in Scheme 3. In addition, ligands such as pyridineimines, ${ }^{35}$ picolylamines, ${ }^{36}$ cyclic amines ${ }^{37}$ and phenanthrolines ${ }^{38}$ have also been used.

\section{[Insert Scheme 3]}

The activation rate constants were determined in $\mathrm{CH}_{3} \mathrm{CN}$ at variable temperatures using previously reported experimental procedures ${ }^{18}$ with the exception that an excess of alkyl halide (RX) and TEMPO were used and the rates were determined by monitoring the disappearance of the copper complex according to $\ln \left(\left[\mathrm{Cu}^{\mathrm{I} X} / \mathrm{L}_{n}\right]_{0} /\left[\mathrm{Cu}^{\mathrm{I} X} / \mathrm{L}_{n}\right]_{t}\right)=\mathrm{k}_{\mathrm{obs}} \mathrm{t}=$ $-\mathrm{k}_{\text {act }}[\mathrm{RX}]_{0} \mathrm{t}$. Typically, $10-25$ equivalents of $\mathrm{RX}$ and TEMPO relative to the starting $\mathrm{Cu}^{\mathrm{I} X} / \mathrm{L}_{\mathrm{n}}$ complex were used, with $\left[\mathrm{Cu}^{\mathrm{I}} \mathrm{X} / \mathrm{L}_{\mathrm{n}}\right]_{0}=1.0 \times 10^{-3} \mathrm{M}-3.0 \times 10^{-3} \mathrm{M}$. The kinetic runs were carried out with a Hitech SF-61-DX2 apparatus equipped with a $1 \mathrm{~cm}$ quarz cell and coupled with a Hitech diode-array UV-visible spectrophotometer. Such excess amount of TEMPO was found sufficient to insure a complete radical trapping and the total suppression of the deactivation process (see Scheme 2). These conditions were chosen primarily because of the strong interference of TEMPO in the UV region of the absorption spectra which does not enable the determination of the concentrations of alkyl halide accurately. The observed rate constant $\left(k_{o b s}=k_{a c t}[R X]_{0}\right)$ and reaction order were determined using commercially available SpecFit program. ${ }^{39}$

Shown in Figure 1 is the typical time dependent absorption spectra recorded for the

\section{[Insert Figure 1]}

reaction of $\mathrm{Cu}^{\mathrm{I}} \mathrm{Br} / 2 \mathrm{dNbpy}$ in the presence of excess EBriB and TEMPO in $\mathrm{CH}_{3} \mathrm{CN}$ at 25 ${ }^{\circ} \mathrm{C}$. As indicated in Figure 1, during the progress of the reaction the decrease of the 
absorption spectra in the 400-650 $\mathrm{nm}$ region is accompanied by a corresponding increase in the $650-800 \mathrm{~nm}$ region. The latter indicates the formation of the $\mathrm{Cu}^{\mathrm{II}} \mathrm{Br}_{2} / 2 \mathrm{dNbpy}$ complex whose spectrum has been fully characterized. ${ }^{40-42}$ Data analysis performed using the SpecFit program indicated first order reaction conditions with observed rate constant of $\mathrm{k}_{\mathrm{obs}}=0.053 \mathrm{~s}^{-1}$, from which the activation rate constant was calculated as $\mathrm{k}_{\mathrm{act}}=0.78$ $\mathrm{M}^{-1} \mathrm{~s}^{-1}$. Similarly, the rates at different temperatures can be used to determine the activation parameters, $\Delta \mathrm{H}^{\neq}$and $\Delta \mathrm{S}^{\neq}$, as shown in Figure 2. The advantage of the stoppedflow technique in terms of accessing

\section{[Insert Figure 2]}

very high reaction rates was first demonstrated in the case of relatively active $\mathrm{Cu}^{\mathrm{I}} \mathrm{Br} / \mathrm{Me}_{6} \mathrm{TREN}$ system and $\mathrm{PEBr}$ under pseudo-first order reaction conditions in $\mathrm{CH}_{3} \mathrm{CN}$ at $15{ }^{\circ} \mathrm{C}$ (Figure 3).

\section{[Insert Figure 3]}

The activation rate constant for this system at $25^{\circ} \mathrm{C}$ was determined to be $\mathrm{k}_{\mathrm{act}}=8.6 \times 10^{2}$ $\mathrm{M}^{-1} \mathrm{~s}^{-1}$. A study of $\mathrm{Cu}^{\mathrm{I}} \mathrm{Br} / \mathrm{Me}_{6} \mathrm{TREN}$ and MBP under the same reaction conditions and temperature revealed a slightly more reactive system with $\mathrm{k}_{\mathrm{act}}=1.1 \times 10^{3} \mathrm{M}^{-1} \mathrm{~s}^{-1}$. While systems faster than these can still be measured using pseudo first order reaction conditions, more scans and hence more reliable data can be obtained using second order conditions (i.e. stoichiometric amounts of $\mathrm{Cu}^{\mathrm{I}} \mathrm{X} / \mathrm{L}_{\mathrm{n}}$ complex and alkyl halide $\mathrm{RX}$ ). The activation rate constant for $\mathrm{Cu}^{\mathrm{I}} \mathrm{Br} / \mathrm{Me}_{6} \mathrm{TREN}$ and $\mathrm{EBriB}$ was determined under second order conditions in $\mathrm{CH}_{3} \mathrm{CN}$ at $25{ }^{\circ} \mathrm{C}$ as $\mathrm{k}_{\text {act }}=7.7 \times 10^{3} \mathrm{M}^{-1} \mathrm{~s}^{-1}$, or approximately 10,000 times faster than the $\mathrm{Cu}^{\mathrm{I}} \mathrm{Br} / 2 \mathrm{dNbpy}$ system under the same experimental conditions. The 
activation rate constants and parameters $\left(\Delta \mathrm{H}^{\neq}\right.$and $\left.\Delta \mathrm{S}^{\neq}\right)$, determined for the copper(I) complexes and alkyl halides in $\mathrm{CH}_{3} \mathrm{CN}$, are summarized in Table 1.

\section{[Insert Table 1]}

The activation rate constants for $\mathrm{Cu}^{\mathrm{I}} \mathrm{Br} / 2 \mathrm{dNbpy}$ and $\mathrm{Cu}^{\mathrm{I}} \mathrm{Br} / \mathrm{PMDETA}$ systems are in good agreement with previously reported values using GC techniques. ${ }^{18,26,27,30}$ Furthermore, the activation parameters for $\mathrm{PEBr}$ and $\mathrm{EBriB}$ using $\mathrm{Cu} \mathrm{I} \mathrm{Br} / 2 \mathrm{dNB} p \mathrm{y}$, $\mathrm{Cu}^{\mathrm{I}} \mathrm{Br} / \mathrm{PMDETA}$ and $\mathrm{Cu}^{\mathrm{I}} \mathrm{Br} / \mathrm{Me}_{6}$ TREN complexes can now be used to calculate the corresponding activation rate constants at polymerization temperatures $\left(\mathrm{T}=60-110{ }^{\circ} \mathrm{C}\right)$. While it has been shown that PEBr is a good model compound for a polystyrene chain end, ${ }^{20}$ the same might not hold for EBriB and methyl methacrylate, due to the recently demonstrated penultimate effect. ${ }^{30}$ These activation parameters for $\mathrm{Cu}^{\mathrm{I}} \mathrm{Br} / \mathrm{Me}_{6}$ TREN that were previously unavailable, and the activation data for other highly reactive systems yet to be measured, will be critical when modeling the kinetics of such polymerization systems. $^{43}$

As indicated in Table 1, the activation rate constants for $\mathrm{Cu}^{\mathrm{I}} \mathrm{Br} / \mathrm{Me}_{6} \mathrm{TREN}$ are much higher than for $\mathrm{Cu}^{\mathrm{I}} \mathrm{Br} / 2 \mathrm{dNbpy}$ and $\mathrm{Cu}^{\mathrm{I}} \mathrm{Br} / \mathrm{PMDETA}$ complexes. This is reflected in their redox potentials, and our previous investigation of these systems indicated that $\mathrm{Cu}^{\mathrm{I}} \mathrm{Br} / \mathrm{Me}_{6} \mathrm{TREN}$ is a much more reducing catalyst. ${ }^{44}$ We are also attempting to correlate the activation rate constant and the catalyst structure as well as exploring the determination of the deactivation rate constants via measurements of the overall equilibrium constant for ATRP $\left(\mathrm{K}_{\mathrm{ATRP}}=\mathrm{k}_{\mathrm{act}} / \mathrm{k}_{\text {deact }}\right)$ using persistent radical effect.

When the stopped-flow apparatus is set up on the bench top, there is the potential for slow diffusion of oxygen through the apparatus to the sample. Monitoring the 
absorbance spectra of $\mathrm{Cu}^{\mathrm{I}} \mathrm{Br} / 2 \mathrm{dNbpy}$ in the apparatus for 1000 seconds in the absence of alkyl halide revealed the complex was slowly oxidized $(<10 \%)$. This oxidation was not significant enough to affect the measurement of activation rate constants for $\mathrm{Cu}^{\mathrm{I}} \mathrm{Br} / 2 \mathrm{dNbpy}$ and $\mathrm{EBriB}$ because the reaction was complete long before significant diffusion of oxygen through the system could occur.

In conclusion, the stopped-flow technique was used to determine the activation rate constants in $\mathrm{CH}_{3} \mathrm{CN}$ at variable temperatures for alkyl halides and very active $\mathrm{Cu} \mathrm{I} / \mathrm{L}_{\mathrm{n}}$ complexes, which were previously not accessible due to the limitations in measuring fast reaction rates with current GC and NMR techniques. The activation rate constants for $\mathrm{EBriB}$ were found to increase in the order $\mathrm{Cu}^{\mathrm{I}} \mathrm{Br} / 2 \mathrm{dNbpy}<$ $\mathrm{Cu}^{\mathrm{I}} \mathrm{Br} / \mathrm{PMDETA} \ll \mathrm{Cu}^{\mathrm{I}} \mathrm{Br} / \mathrm{Me}_{6}$ TREN. The rate constants of activation $\left(\mathrm{k}_{\mathrm{act}}\right)$ for $\mathrm{PEBr}$ $\left(8.6 \times 10^{2} \mathrm{M}^{-1} \mathrm{~s}^{-1}\right)$, MBP $\left(1.1 \times 10^{3} \mathrm{M}^{-1} \mathrm{~s}^{-1}\right)$ and $\operatorname{EBriB}\left(7.7 \times 10^{3} \mathrm{M}^{-1} \mathrm{~s}^{-1}\right)$ at $25{ }^{\circ} \mathrm{C}$ for the $\mathrm{Cu}^{\mathrm{I}} \mathrm{Br} / \mathrm{Me}_{6} \mathrm{TREN}$ complex were found to be orders of magnitude higher than the corresponding $\mathrm{Cu}^{\mathrm{I}} \mathrm{Br} / 2 \mathrm{dNbpy}$ and $\mathrm{Cu}^{\mathrm{I}} \mathrm{Br} / \mathrm{PMDETA}$ complexes. The demonstrated effectiveness of the stopped-flow technique to measure fast reaction rates opens a new way to systematically determine activation rate constants and activation parameters for other highly active ATRP complexes.

\section{Acknowledgements}

The financial support from the CMU CRP Consortium and the NSF grant (CHE0096601) is greatly appreciated. RP and EC thank the Conseil Régional de Bourgogne for funds that allowed the purchase of the stopped-flow apparatus. 
Supporting Information Available. Detailed experimental procedures, Arrhenius plots for the determination of $\Delta \mathrm{H}^{\neq}$and $\Delta \mathrm{S}^{\neq}$, as well as time dependent absorption spectra for alkyl halides and copper(I) complexes used in the study (PDF). This material is available free of charge via the Internet at http://pubs.acs.org

\section{References}

(1) Matyjaszewski, K.; Davis, T. P. Handbook of Radical Polymerization; John Wiley \& Sons, Inc.: Hoboken, 2002.

(2) Matyjaszewski, K.; Xia, J. Chem. Rev. 2001, 101, 2921-2990.

(3) Kamigaito, M.; Ando, T.; Sawamoto, M. Chem. Rev. 2001, 101, 36893745 .

(4) Wang, J.-S.; Matyjaszewski, K. J. Am. Chem. Soc. 1995, 117, 5614-5615.

(5) Patten, T. E.; Xia, J.; Abernathy, T.; Matyjaszewski, K. Science 1996, 272, $866-868$.

(6) Matyjaszewski, K.; Patten, T. E.; Xia, J. J. Am. Chem. Soc 1997, 119, 674-680.

(7) Xia, J.; Matyjaszewski, K. Macromolecules 1997, 30, 7697-7700.

(8) Xia, J.; Gaynor, S. G.; Matyjaszewski, K. Macromolecules 1998, 31, 5958-5959.

(9) Xia, J.; Zhang, X.; Matyjaszewski, K. In Transition Metal Catalysis in Macromolecular Design; Boffa, L. S., Novak, B. M., Eds.; Am. Chem. Soc.: Washington, D. C., 2000; Vol. 760, pp 207-223.

(10) Fischer, H. Chem. Rev. 2001, 101, 3581-3610.

(11) Coessens, V.; Pintauer, T.; Matyjaszewski, K. Prog. Polym. Sci. 2001, 26, 337-377.

(12) Patten, T. E.; Matyjaszewski, K. Acc. Chem. Res. 1999, 32, 895-903.

(13) Matyjaszewski, K. Chem. Eur. J. 1999, 5, 3095-3102.

(14) Patten, T. E.; Matyjaszewski, K. Adv. Mater. 1998, 10, 901-915.

(15) Davis, K. A.; Matyjaszewski, K. Adv. Polym. Sci. 2002, 159, 30-106.

(16) Pyun, J.; Matyjaszewski, K. Chem. Mater. 2003, 13, 3436-3448.

(17) Pintauer, T.; Zhou, P.; Matyjaszewski, K. J. Am. Chem. Soc. 2002, 124,

(18) Matyjaszewski, K.; Paik, H.-j.; Zhou, P.; Diamanti, S. J. Macromolecules 2001, 34, 5125-5131.

(19) Goto, A.; Fukuda, T. Macromol. Rapid Commun. 1999, 20, 633-636.

(20) Ohno, K.; Goto, A.; Fukuda, T.; Xia, J.; Matyjaszewski, K. Macromolecules 1998, 31, 2699-2701.

(21) Auke, S.; Klumperman, B.; Van der Linde, R. Macromolecules 2002, 35, 4785-4790. 
(22) Chambard, G.; Klumperman, B.; German, A. L. Macromolecules 2002, $35,3420-3425$.

(23) Zhang, H.; Klumperman, B.; Ming, W.; Fischer, H.; van der Linde, R. Macromolecules 2001, 34, 6169-6173.

(24) Chambard, G.; Klumperman, B.; German, A. L. Macromolecules 2002, $35,3420-3425$.

(25) Yoshikawa, C.; Goto, A.; Fukuda, T. Macromolecules 2003, 36, 908-912.

(26) Nanda, A. K.; Matyjaszewski, K. Macromolecules 2003, 36, 599-604.

(27) Nanda, A. K.; Matyjaszewski, K. Macromolecules 2003, 36, 1487-1493.

(28) Matyjaszewski, K.; Gobelt, B.; Paik, H.-j.; Horwitz, C. P. Macromolecules 2001, 34, 430-440.

(29) Chambard, G.; Klumperman, B.; German, A. L. Macromolecules 2000, 33, $4417-4421$.

(30) Nanda, A. K.; Matyjaszewski, K. Macromolecules 2003, ASAP.

(31) Beckwith, A. L. J.; Bowry, V. W.; Ingold, K. U. J. Am. Chem. Soc. 1992, 114, 4983-4992.

(32) Beckwith, A. L. J.; Bowry, V. W.; Moad, G. J. Org. Chem. 1988, 53, $1632-1641$.

(33) Chateauneuf, J.; Lusztyk, J.; Ingold, K. U. J. Org. Chem. 1988, 53, 1629 1632.

(34) Gromada, J.; Matyjaszewski, K. Macromolecules 2002, 35, 6167-6173.

(35) Haddleton, D. M.; Jasieczek, C. B.; Hannon, M. J.; Shooter, A. J. Macromolecules 1997, 30, 2190-2193.

(36) Xia, J.; Matyjaszewski, K. Macromolecules 1999, 32, 2434-2437.

(37) Teodorescu, M.; Matyjaszewski, K. Macromolecules 1999, 32, 48264831.

(38) Destarac, M.; Bessiere, J. M.; Boutevin, B. Macromol. Rapid Commun. 1997, 18, 967-974.

(39) Binstead, R. A.; Jung, B.; Zuberbühler, A. D.; 2000 Spectrum Software Associates: Chapel Hill, NC, 2000.

(40) Pintauer, T.; Qiu, J.; Kickelbick, G.; Matyjaszewski, K. Inorg. Chem. 2001, 40, 2818-2824.

(41) Murphy, G.; O'Sullivan, C.; Murphy, B.; Hathaway, B. Inorg. Chem. 1998, 37, 240-248.

(42) O'Sullivan, C.; Murphy, G.; Murphy, B.; Hathaway, B. J. Chem. Soc. Dalton Trans. 1999, 11, 1835-1844.

(43) Gillies, M. B.; Matyjaszewski, K.; Norrby, P.-O.; Pintauer, T.; Poli, R.; Richard, P. Macromolecules 2003, 36, 8551-8559.

(44) Qiu, J.; Matyjaszewski, K.; Thouin, L.; Amatore, C. Macromol. Chem. Phys. 2000, 201, 1625-1631. 
Table 1. Summary of activation rate constants in $\mathrm{CH}_{3} \mathrm{CN}$ for various copper(I) complexes and initiators used in the ATRP as determined using stopped-flow technique.

\begin{tabular}{|c|c|c|c|c|c|c|}
\hline Complex & Initiator & Rxn Order & $\mathrm{T} / /^{\circ} \mathrm{C}$ & $\mathrm{k}_{\mathrm{act}} / \mathrm{M}^{-1} \mathrm{~s}^{-1}$ & $\Delta \mathrm{H}^{\neq} / \mathrm{kJmol}^{-1 \mathrm{a}}$ & $\Delta \mathrm{S}^{\neq} / \mathrm{JK}^{-1} \mathrm{~mol}^{-1 \mathrm{a}}$ \\
\hline $\mathrm{Cu}^{\mathrm{I}} \mathrm{Br} / 2 \mathrm{dNbpy}$ & EBriB & Pseudo $1^{\text {st }}$ & $\begin{array}{l}15 \\
25 \\
35\end{array}$ & $\begin{array}{c}0.49 \pm 0.01 \\
0.78 \pm 0.02 \\
1.3 \pm 0.05\end{array}$ & $33.5 \pm 1.7$ & $-134 \pm 6$ \\
\hline $\mathrm{Cu}{ }^{\mathrm{I}} \mathrm{Br} / \mathrm{PMDETA}$ & EBriB & Pseudo $1^{\text {st }}$ & $\begin{array}{l}15 \\
25 \\
35\end{array}$ & $\begin{array}{l}1.4 \pm 0.03 \\
2.3 \pm 0.06 \\
4.3 \pm 0.07\end{array}$ & $38.9 \pm 3.6$ & $-107 \pm 12$ \\
\hline \multirow[t]{3}{*}{$\mathrm{Cu}^{\mathrm{I}} \mathrm{Br} / \mathrm{Me}_{6} \mathrm{TREN}$} & $\mathrm{PEBr}$ & Pseudo $1^{\text {st }}$ & $\begin{array}{c}5 \\
15 \\
25 \\
35\end{array}$ & $\begin{array}{l}(4.5 \pm 0.2) \times 10^{2} \\
(6.7 \pm 0.2) \times 10^{2} \\
(8.6 \pm 0.3) \times 10^{2} \\
(1.2 \pm 0.3) \times 10^{3}\end{array}$ & $20.3 \pm 1.2$ & $-120 \pm 4$ \\
\hline & EBriB & $2^{\text {nd }}$ & $\begin{array}{l}15 \\
20 \\
25\end{array}$ & $\begin{array}{l}(5.7 \pm 0.3) \times 10^{3} \\
(6.9 \pm 0.1) \times 10^{3} \\
(7.7 \pm 0.2) \times 10^{3}\end{array}$ & $19.3 \pm 3.1$ & $-106 \pm 11$ \\
\hline & MBP & Pseudo $1^{\text {st }}$ & 25 & $(1.1 \pm 0.3) \times 10^{3}$ & & \\
\hline
\end{tabular}

${ }^{\mathrm{a}}$ For fit index $\left(\mathrm{R}^{2}\right)$ see Figure 2 and supporting information. 


\section{Captions for Schemes and Figures}

Scheme 1. Proposed mechanism for ATRP.

Scheme 2. Kinetic isolation of the activation process in the ATRP.

Scheme 3. Structures of model compounds (a) and complexing ligands (b) used in the activation studies.

Figure 1. Time dependent absorption spectra of $\mathrm{Cu}^{\mathrm{I}} \mathrm{Br} / 2 \mathrm{dNbpy}$ in the presence of $\mathrm{EBriB}$ in $\mathrm{CH}_{3} \mathrm{CN}$ at $25{ }^{\circ} \mathrm{C} . \quad\left[\mathrm{Cu}{ }^{\mathrm{I}} \mathrm{Br} / 2 \mathrm{dNbpy}\right]_{0}:[\mathrm{EBriB}]_{0}:[\mathrm{TEMPO}]_{0}=1: 20: 20$, $\left[\mathrm{Cu}{ }^{\mathrm{I}} \mathrm{Br} / 2 \mathrm{dNbpy}\right]_{0}=2.7 \times 10^{-3} \mathrm{M}$, spectra recorded every $1 \mathrm{~s}\left(\mathrm{t}_{\mathrm{start}}=0.5 \mathrm{~s}, \mathrm{t}_{\mathrm{end}}=70.5 \mathrm{~s}\right)$.

Figure 2. Arrhenius plot for the reaction between $\mathrm{Cu}^{\mathrm{I}} \mathrm{Br} / 2 \mathrm{dNbpy}$ and $\mathrm{EBriB}$ in $\mathrm{CH}_{3} \mathrm{CN}$ (experimental conditions are given in Figure 1).

Figure 3. Time dependent absorption spectra of $\mathrm{Cu}^{\mathrm{I}} \mathrm{Br} / \mathrm{Me}_{6} \mathrm{TREN}$ in the presence of $\mathrm{PEBr}$ in $\mathrm{CH}_{3} \mathrm{CN}$ at $15{ }^{\circ} \mathrm{C} . \quad\left[\mathrm{Cu}{ }^{\mathrm{I}} \mathrm{Br} / \mathrm{Me}_{6} \mathrm{TREN}\right]_{0}:[\mathrm{PEBr}]_{0}:[\mathrm{TEMPO}]_{0}=1: 20: 20$, $\left[\mathrm{Cu}{ }^{\mathrm{I} B r} / \mathrm{Me}_{6} \mathrm{TREN}\right]_{0}=2.7 \times 10^{-3} \mathrm{M}, 160$ scans, $\left(\mathrm{t}_{\text {start }}=0.002 \mathrm{~s}, \mathrm{t}_{\text {end }}=3.80 \mathrm{~s}\right)$. 


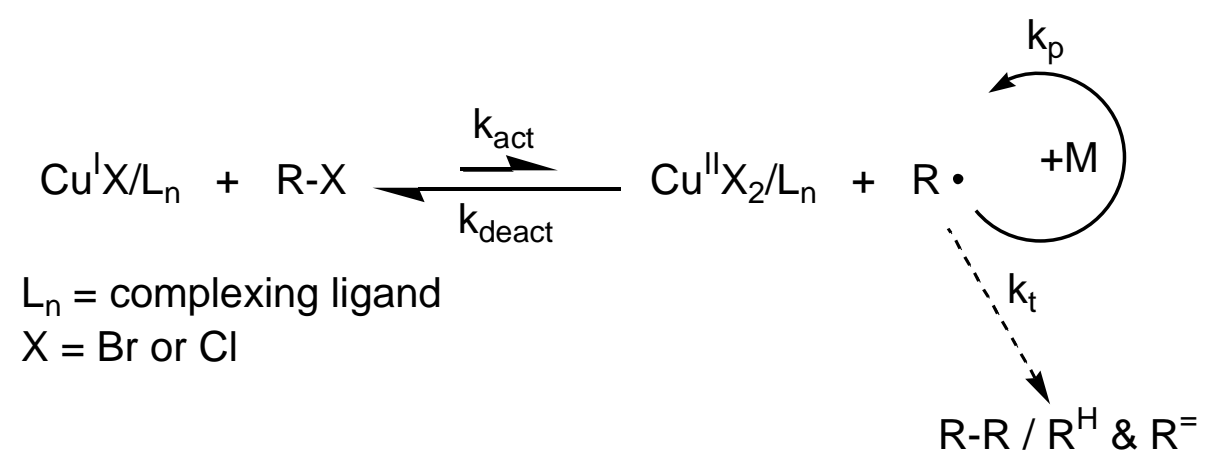

Scheme 1. Proposed mechanism for ATRP. 


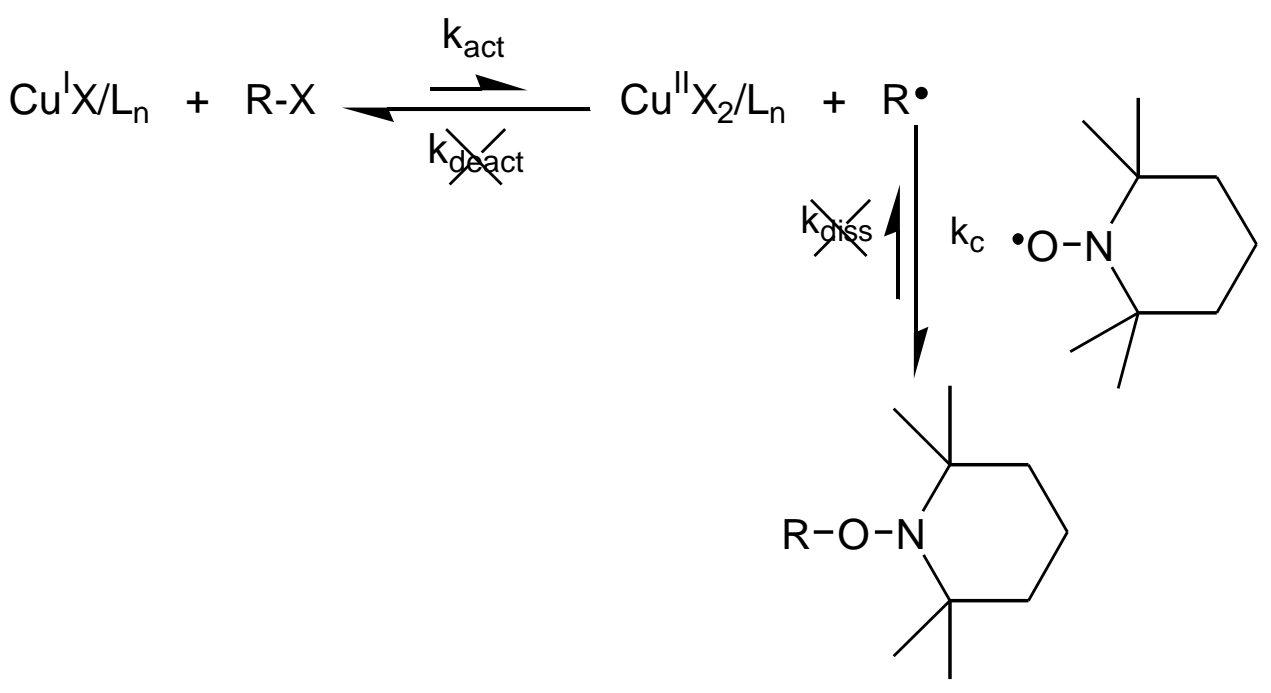

Scheme 2. Kinetic isolation of the activation process in the ATRP. 

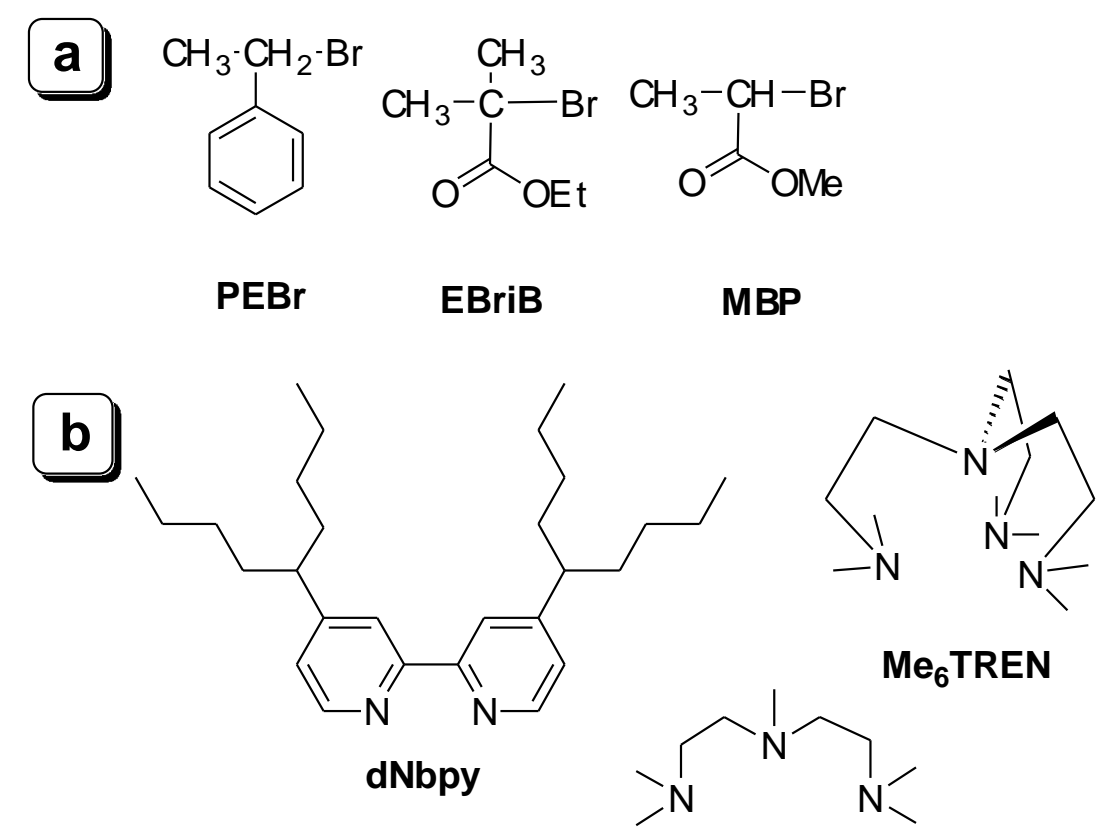

PMDETA

Scheme 3. Structures of model compounds (a) and complexing ligands (b) used in the activation studies. 


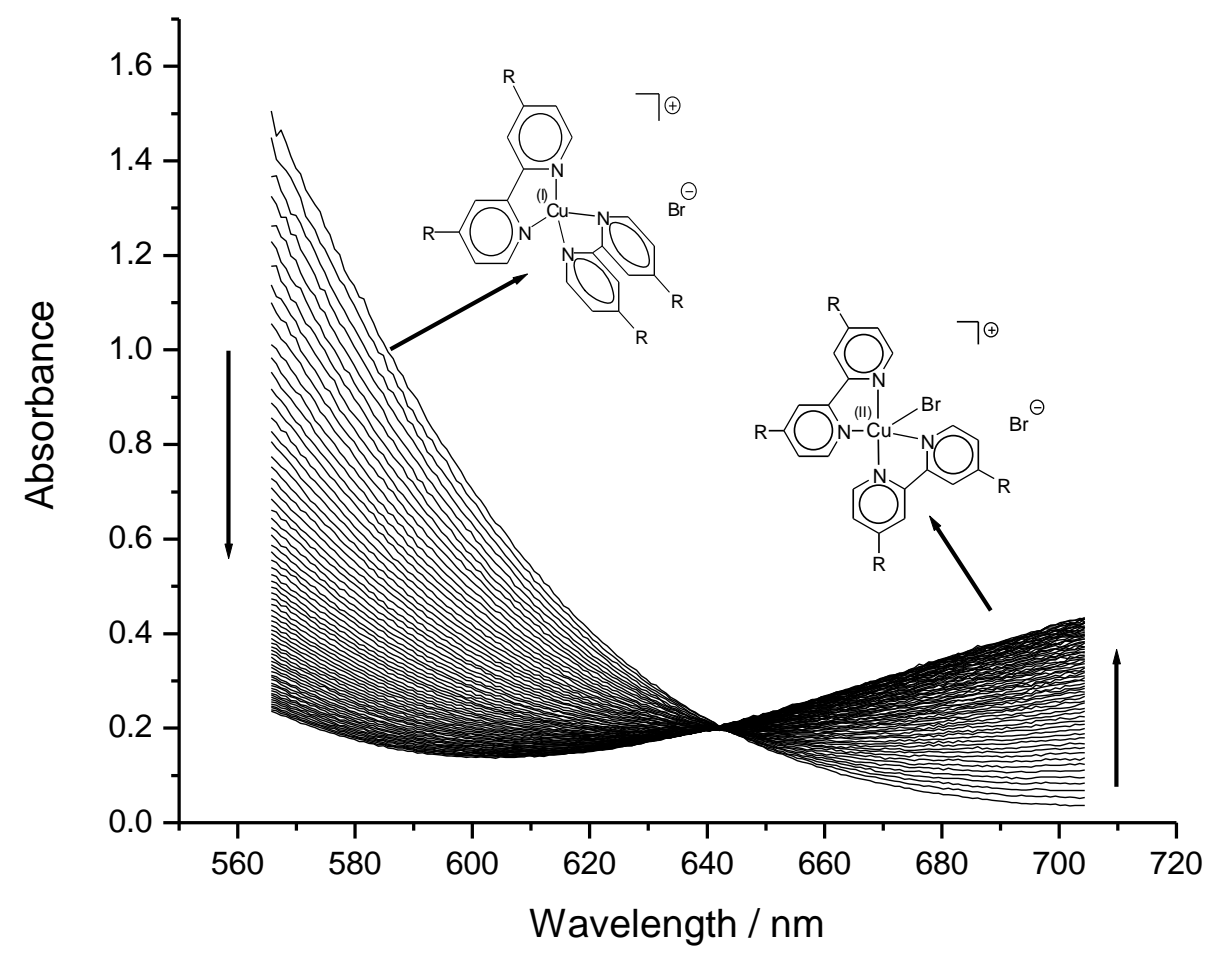

Figure 1. Time dependent absorption spectra of $\mathrm{Cu}^{\mathrm{I}} \mathrm{Br} / 2 \mathrm{dNbpy}$ in the presence of EBriB in $\mathrm{CH}_{3} \mathrm{CN}$ at $25{ }^{\circ} \mathrm{C} . \quad\left[\mathrm{Cu}{ }^{\mathrm{I}} \mathrm{Br} / 2 \mathrm{dNbpy}\right]_{0}:[\mathrm{EBriB}]_{0}:[\mathrm{TEMPO}]_{0}=1: 20: 20$, $\left[\mathrm{Cu}^{\mathrm{I}} \mathrm{Br} / 2 \mathrm{dNbpy}\right]_{0}=2.7 \times 10^{-3} \mathrm{M}$, spectra recorded every $1 \mathrm{~s}\left(\mathrm{t}_{\mathrm{start}}=0.5 \mathrm{~s}, \mathrm{t}_{\text {end }}=70.5 \mathrm{~s}\right)$. 


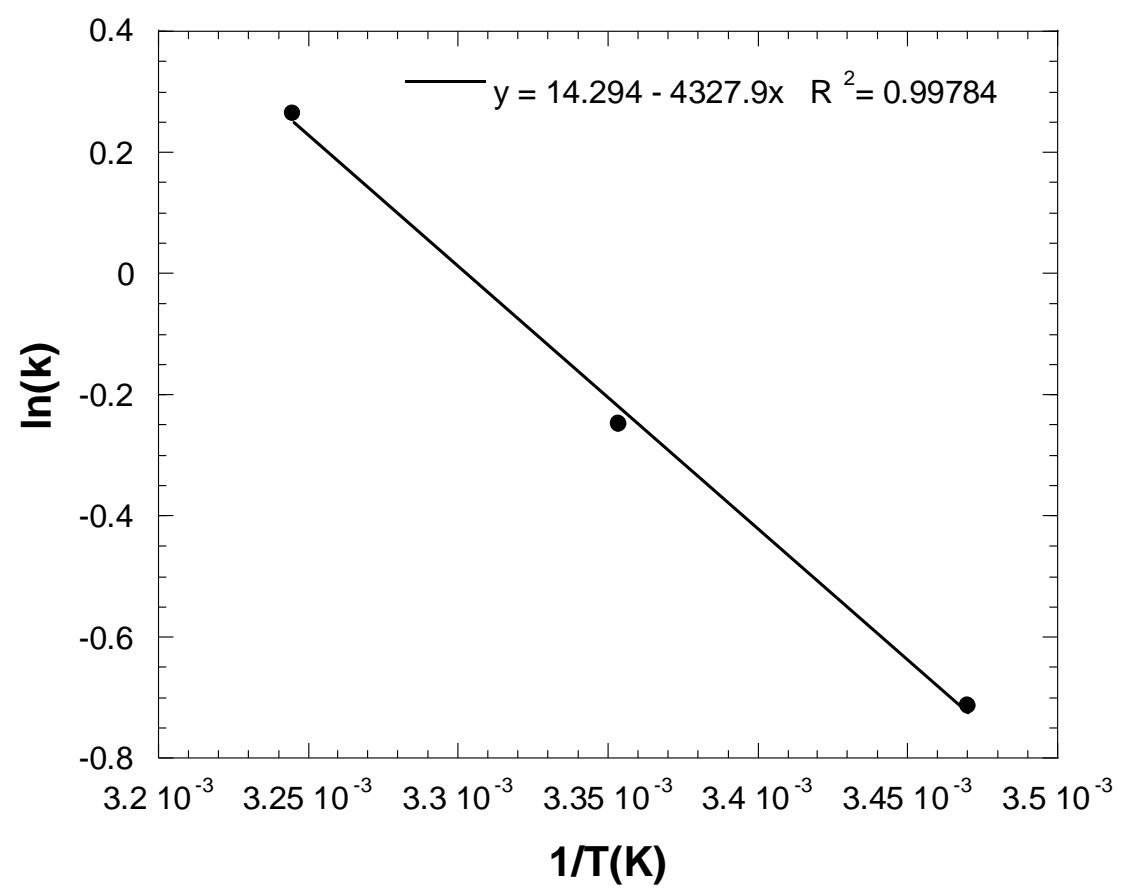

Figure 2. Arrhenius plot for the reaction between $\mathrm{Cu}^{\mathrm{I}} \mathrm{Br} / 2 \mathrm{dNbpy}$ and $\mathrm{EBriB}$ in $\mathrm{CH}_{3} \mathrm{CN}$ (experimental conditions are given in Figure 1). 


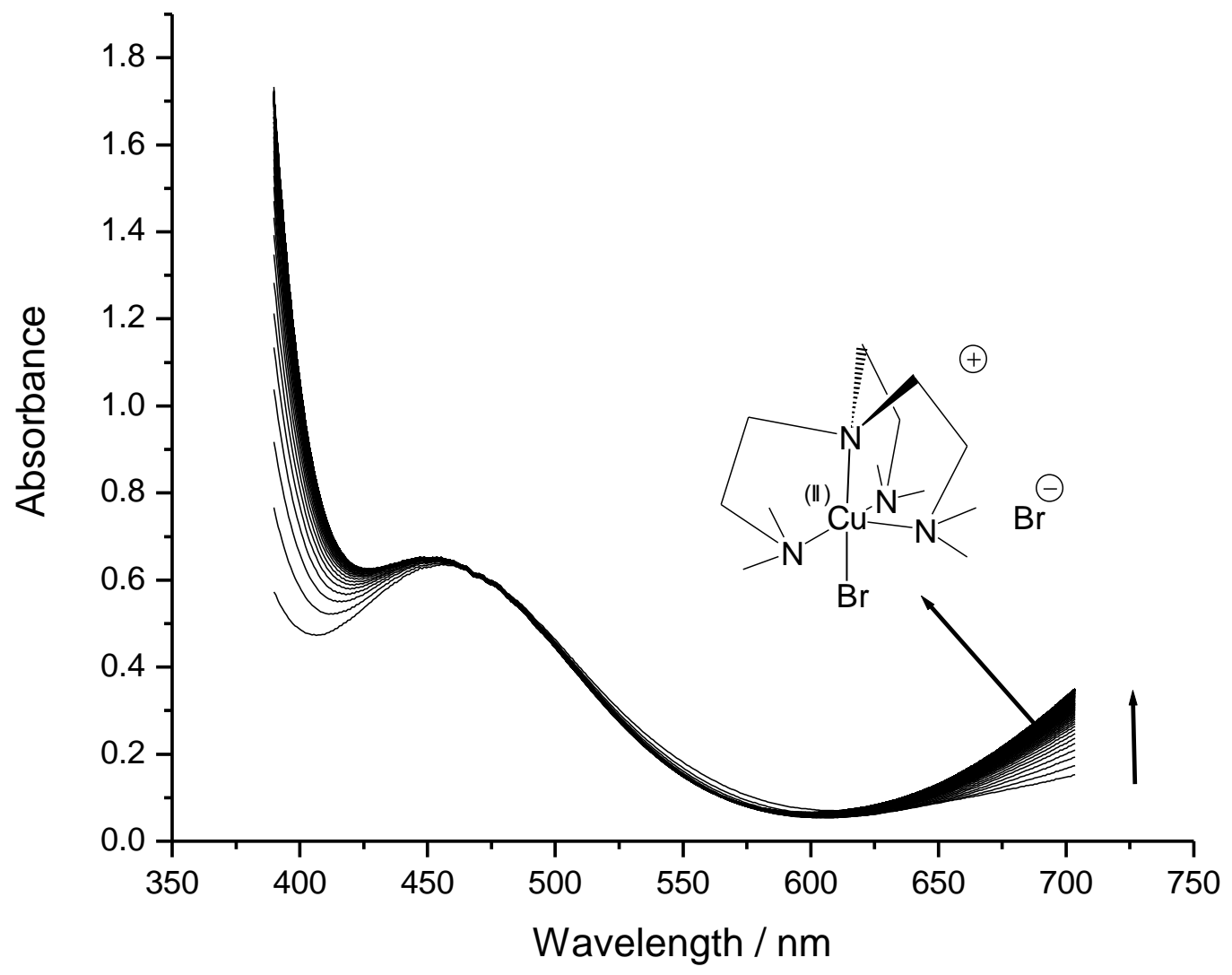

Figure 3. Time dependent absorption spectra of $\mathrm{Cu}^{\mathrm{I}} \mathrm{Br} / \mathrm{Me}_{6} \mathrm{TREN}$ in the presence of $\mathrm{PEBr}$ in $\mathrm{CH}_{3} \mathrm{CN}$ at $15{ }^{\circ} \mathrm{C} .\left[\mathrm{Cu}{ }^{\mathrm{I}} \mathrm{Br} / \mathrm{Me}{ }_{6} \mathrm{TREN}\right]_{0}:[\mathrm{PEBr}]_{0}:[\mathrm{TEMPO}]_{0}=1: 20: 20$, $\left[\mathrm{Cu}{ }^{\mathrm{I}} \mathrm{Br} / \mathrm{Me}_{6} \mathrm{TREN}_{0}=2.7 \times 10^{-3} \mathrm{M}, 160\right.$ scans, $\left(\mathrm{t}_{\text {start }}=0.002 \mathrm{~s}, \mathrm{t}_{\text {end }}=3.80 \mathrm{~s}\right)$. 